Etikonomi

Volume 16 (2), Oktober 2017

P-ISSN: 1412-8969; E-ISSN: 2461-0771

Page 265 - 278

\title{
Development Strategy of Micro-takaful Institutions: Case Study Working Group Indonesia
}

\author{
Aam Slamet Rusydiana, Abrista Devi \\ ${ }^{1,2}$ SMART Consulting, ${ }^{2}$ Ibn Khaldun University \\ 12aamsmart@gmail.com, ${ }^{2}$ brista_quechi@yahoo.com
}

\begin{abstract}
Indonesia is becoming one of potential countries in micro-takaful institutions development. One of the expert in micro-takaful is Takmin Working Group. TWG is a group of initiators who have commitment to develop micro takaful in Indonesia. Its members consist ofexperts in Islamic insurance, micro finance and accounting. The research objectives of this study are to identify and analyze the problems faced by TWG in developing of micro-takaful institutions and identify the solutions to solve those kinds of problems, by using Analytic Hierarchy Process (AHP) method. The finding of this study shows the most priority solutions that can be undertake by Takmin Working Group to solve these both internal and external problem is information system development, and then followed by innovative product development. Communication \&o visitation to Islamic micro finance institutions and socialization about micro-takaful product to society are being less priority on this matter.
\end{abstract}

Keywords: Micro-takaful, Takmin Working Group, Analytic Hierarchy Process

\begin{abstract}
Abstrak
Indonesia adalah salah satu Negara potensial dalam pengembangan institusi takaful mikro. Salah satu abli dalam pengembangan takaful mikro adalab Takmin Working Group.TWG adalah grup inisiator yang berkomitmen terbadap pengembangan takaful mikro di Indonesia. Anggotanya terdiri dari para abli dalam asuransi syariah, keuangan mikro dan akuntansi. Tujuan penelitian ini adalah untuk. mengidentifikasi masalah yang dihadapi TWG dalam pengembangan takaful mikro dan menemukan solusinya dengan metode Analytic Hierarchy Process (AHP). Temuan dalam studi ini menunjukekan babwa solusi yang prioritas dalam menyelesaikan masalah internal dan eksternal adalah pengembangan sistem informasi dan pengembangan produk yang inovatif. Komunikasi dan kunjungan terhadap lembaga keuangan mikero serta sosialisasi terkait produk takaful mikro kepada masyarakat menjadi prioritas selanjutnya.
\end{abstract}

Kata Kunci: mikro-takaful, kelompok kerja Takmin, analytic network process

Received: April 15, 2017; Revised: July 9, 2017; Approved: July 19, 2017 
Development Strategy of Micro-Takaful Institutions..........

Aam Slamet Rusydiana, Abrista Devi

\section{INTRODUCTION}

Indonesia is becoming one of potential countries in micro takaful institutions development. According to the 2013 Millenium development Goals report suggested that $60 \%$ of populations in the developing world live on less than $\$ 4$ a day. In Indonesia, it was recorded from Indonesia's total populations (238.518.800 million people), there are approximately 144.111.280 people that live on less than $\$ 4$ a day. In line with BPS data reported that a total of 28.553.930 Indonesians living under the poverty line. Another report said that the most priority Indonesians occupations are agriculture, informal worker, fishery, and small business owners. Unfortunately, their awareness of using micro takaful product is still low (Malagardis, et al, 2014). One of shocking information from the study undertaken by Obaidullah\&Tariqullah (2008) that just five of its 56 Islamic Development Bank (IDB) member countries (involve: Indonesia, Bangladesh, Pakistan, Nigeria, and Egypt) account for over half a billion (528 million) of the world's poor with incomes below $\$ 2$ a day or below their national poverty lines.

Microinsurance is insurance and more simply is a special category of insurance and not new category insurance. Microinsurance is actually aimed to protect the poor, because of there is an element of a social prottction system, similar to social insurances and national health insurance schemes (Hasim, 2014). Microinsurance intends to offer the poor protection against specific risks in return for payment of regular premiums proportionate to the likelihood and cost of the risk involved (FDC \& Citigroup Foundation, 2006). Takmin Working Group is a group of initiators who have commitment to develop micro takaful in Indonesia. Its members consist ofexperts in Islamic insurance, micro finance and accounting. Takmin Working Group (TWG) at first worked with PT. Syarikat Takaful Indonesia in developing and marketing the products. This approach, in the world's Microinsurance practice is known as institutional approach or "Partner Agent Model".

Takaful means a commitment to help each other through contribution in the form of tabarru' without any expected and quick return.In Islamic traditions, the format is to help needy children or orphans to school, to cure the sick, to celebrate family wedding, and to settle funeral of the death, etc.Takaful later on was absorbed as one financial instrument (called as TAKMIN or TADHAAMUN) that is organized in a modern way just like insurance with more number of participants who can give more contributions. Takaful transaction or insurance takaful that serves low income clients is presently known as microtakaful. 
Micro takaful has proven to provide "win-win-win" solutions to the followings: a) for the low income households; by providing them insurance protection that they never experienced before; b) Micro Finance Institutions (MFIs) as the Group's partner can offer better services to their clients with lower risks; and c) Insurance companies are able to tap new market niche (through MFIs) that was previously difficult to approach.

Figure 1: Partner Agency Model of TWG

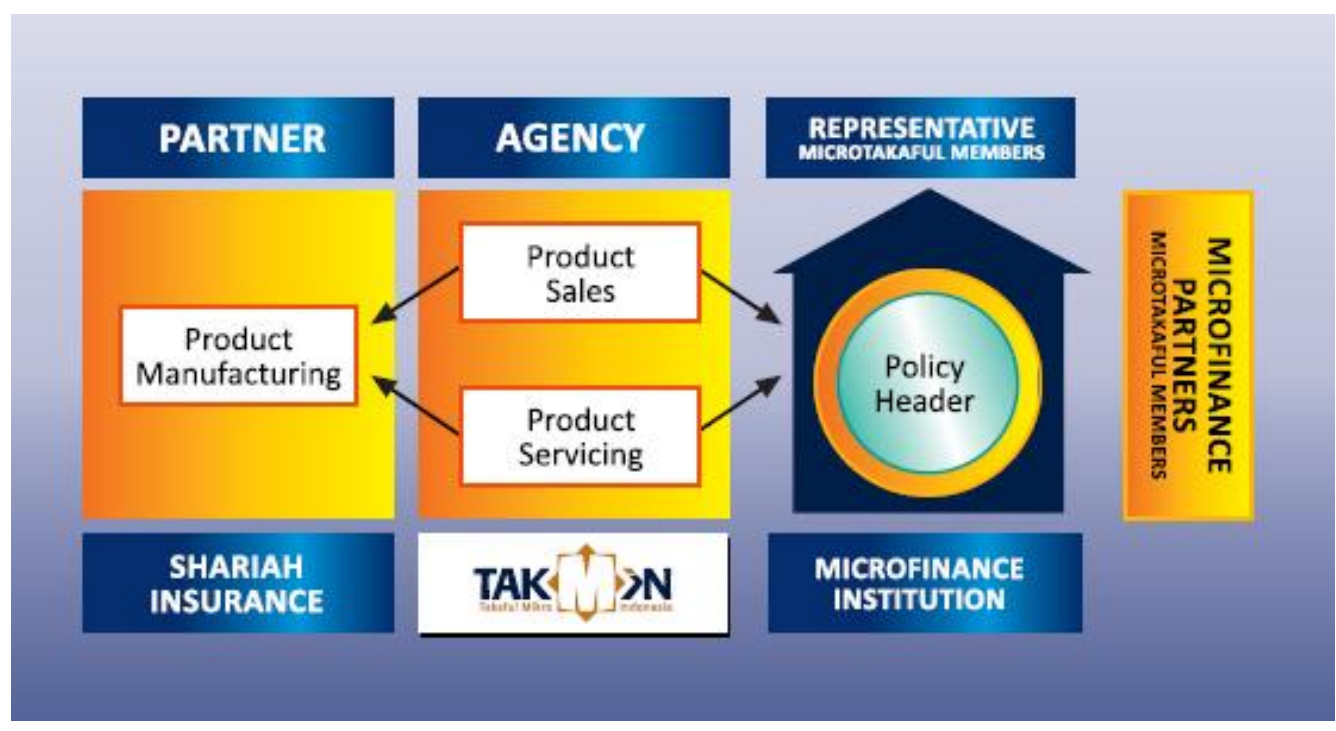

TWG have five pillars of shariah based financing as stage of empowerment. The first pillar is to give charity or a form of contribution to the poor without expecting any return. The charity is delivered to those who are eligible with good manners and education. The second pillar is to give loan. It has better value than charity because when people are borrowing, it means they are in need. Besides, if the loan is well designed, there will be transaction which will create individual responsibility to repay; therefore there must be a commitment to repay on time and in full. The third pillar is to extend financing that is to educate society to develop their wealth through productive business. The fourth pillar is in form of saving intended to educate society to plan their future, by setting aside part of their income to anticipate future needs. The fifth pillar is risk sharing, especially financial risk that occurs due to death, sickness, property loss, house fire, retirement etc. The last pillar can be delivered by micro-takaful instrument.

In order to enhance the development of TWG in Indonesia, this research is aimed to explore the problems faced in TWG's operational system, and then finds the solutions to solve the problems. All problems and solutions were found through interview to some 
Development Strategy of Micro-Takaful Institutions.........

Aam Slamet Rusydiana, Abrista Devi

experts who have knowledge and authority in TWG management office. Hence, this study used soft system methodology, namely Analytic Hierarchy Process.

Based on the research results through literature review and indepth interviews with some respondents who understand the problems and then can argue some solutions to solve the problems appeared, this study showed the decomposition result. The decomposition result shows that there are two main problems in TWG development, there are: (1) Internal Criteria. The problems sometimes come from internal of TWG management system. Such as agency, institutions scale, human resource, funds. Internal Criteria are consists of four sub criteria: a) There are no agency sales; in order to promote Micro Takaful product, TWG has no agency sales which especially doing the promotion. During this time, TWG established cooperation with Islamic Micro Finance Institutions in promoting their product by 'partner agent model' and 'membership process' system. b) Institution scale is relatively small; the scale of TWG institutions is relatively small if compared to another insurance company, both Islamic and conventional institutions with Micro insurance as their main product. c) The lack of human resource capability; TWG also face the quantity and quality of human resource problems. During this time, not all employees have good understanding and knowledge about Islamic transaction contract and Islamic Micro insurance product. d) The lack of promotion fund. In order to do some direct socialization of Islamic Micro insurance product to Islamic Micro Finance Institutions in Indonesia, TWG need the big fund. The constraint is TWG has insufficient fund to promote Islamic Micro insurance product.

(2) External Criteria. The problems is not only coming from internal management of TWG, but also coming from external of TWG management system. Such as societies paradigm, product life cycle, Islamic Micro Finance Institutions routines, and competitions. External criteria are consists of four sub criteria: a) Society paradigm about insurance; there are some groups of Indonesia's society have lack of trust \& lack of knowledge about Islamic insurance scheme. Hence, this problem is becoming the constraint in Micro Takaful development in Indonesia. b) Product life cycle; the saturated market is sometimes happened as the impact of product life cycle. c) Islamic Micro Finance Institutions routines; as a part of TWG agent, Islamic Micro Finance Institutions has no good capability to sell Islamic Micro insurance product because of their routines as micro finance institutions. In another word, it means Islamic Micro insurance products are not being their main product. So the effect is Islamic Micro insurance products is not being prioritized to 
promote. In other side, TWG has no direct structural line to Islamic Micro Finance Institutions agency. d) Market competitions; Islamic Micro insurance product might compete with another Micro insurance product, both Islamic and conventional product from other institutions.

Figure 2: Hierarchy Model of TWG Development Strategy

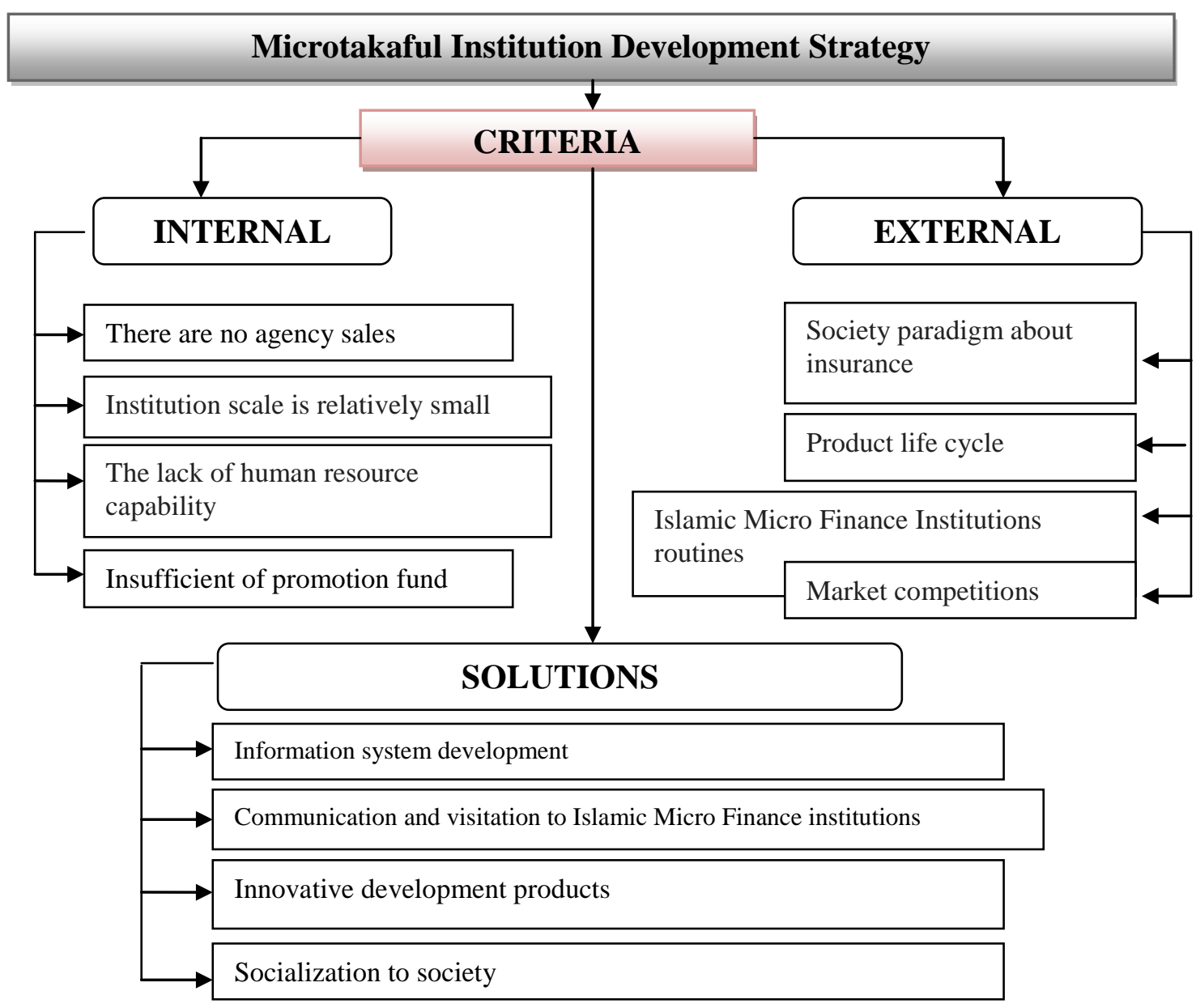

In order to solve all these problems appeared, than this study also show some basically solutions to enhance the development of Takmin Working Group (TWG) as Islamic Micro Institutions. The solutions are consists of four elements, there are: (1) Information system development. TWG might have cooperation with IT provider to develop information system, software application, and integrated networking with other agency of Islamic Micro Finance Institutions; (2) Communication and visitation to Islamic Micro Finance Institutions. One of the most effective solutions in order to create the cooperation with Islamic Micro Finance Institutions is by doing the intensive 
Development Strategy of Micro-Takaful Institutions.........

Aam Slamet Rusydiana, Abrista Devi

communication and visitation at least two times in a year; (3) Innovative development product. TWG must have variety products in order to attract the society to insurance and invest their wealth. The variety of Islamic Micro insurance products will help society to have/buy insurance product based on their need; (4) Socialization to society. The knowledge of Islamic insurance and Micro insurance must be socialized to the society, not only to common society but also to low-income society. The benefit of doing the socialization to common and especially to low income society is it will increase their trust and understanding about Islamic insurance and hopefully in the near future they are attracting to use Micro insurance product. From the explanation, it can be formed on the hierarchy model of development strategy of micro-takaful institutionwith the Analytic Hierarchy Process approach. It can be seen in Figure 2.

\section{METHOD}

This research is using primary data, which is obtained by doing in-depth interview with experts from practitioners and academician. In order to synthesize the problems and make it in priority, second meeting (interview) with experts is needed to complete pair-wise questionnaires. In order to choose respondents in this research is by considering their understanding about micro-takaful development. The amount of respondent consists of five experts related to the topic discussed. There is no maximum or minimum quotes to choose respondent, the most important things to be considered are they must have good ability and good understanding about micro-takaful problem.

This study applies Analytic Hierarchy Process (AHP) methodology in two steps. First, develop an appropriate AHP network and relevant questionnaires to glean the necessary data from experts and academician of microtakaful. Second, AHP analysis is applied to set priority of problem and solutions of TWG strategy on microtakaful product develepment.

\section{RESULT AND DISCUSSION}

The results obtained showed a statistical consensus of the experts and practitioners in relation to problems and solutions to develop micro takaful strategy in Takmin Working Group. In Figure 3, the main problem priority results showed that the problem is coming from external institutions $(55.2 \%)$ and the second priority problem is coming from internal institutions (44.8). Actually, Takmin Working Group needs the highly support from the external parties, such as from regional government and central government, academia, and 
Islamic micro finance institutions. Moreover, they do need the support from society. The need of Islamic micro takaful product must be socialized to all society especially to low level income society in order to protect them selves from any kind of unpredictable situations related to their business/wealth. Unfortunately, some of them believe that they do not need the insurance to protect their business, and in another case they think that the insurance only could spend their money without high impact returns. Some respondents more preferred for conventional insurance due to the following reasons: (a) Past bad experience in Islamic banking; (b) Perception of "takaful" as only a change in name, but with still the same approach; (c) Lack of knowledge about takaful while abundant information about conventional insurance makes for comfortable decision-making; (d) Preference for a national product that everyone would feel comfortable using and would not exclude anyone (See Figure 3).

To prevent the averse of society to Islamic micro insurance, OJK had a program since 2015 in preparing 10 million insurance agency and 1,000 maritime financial friends (or called as "Sahabat Keuangan Maritim"). This program is aimed to increase the social accessibility to insurance service, micro insurance, and enlarge the service scope of financial practices (Hariyadi \& Triyanto, 2017). Hasim (2014) also revealed that to enhance the role of Islamic microfinance towards poverty alleviation need the participation of the government. The government should play an important role in encouraging Islamic insurance operators to design microtakaful schemes to the needy. In addition, the government should also facilitate links to appropriate support organizations such as zakat and waqf institutions, as well as international donors and grant providers. The micro insurance schemes also should have a social protection element, in which the government need to provide the contribution (such as subsidies) to the needy or farmer who cannot afford to buy the policy. The government also needs to establish an intervention fund where it is directly funded from the government's annual budget. The government also needs to develop and implement a supportive regulatory and supervisory framework suitable for microtakaful market. In line with Hasim (2014), Ahuja and Khasnobis (2005) also stated that microtakaful product will become increasingly clear if supported and properly guidance by the regulator as well as the government.

Takmin Working Group actually has a great challenge on how to win society heart in order to move to Islamic takaful, especially know how importance of micro takaful product for their business protection. In addition, another challenge also appeared on how 
Development Strategy of Micro-Takaful Institutions.........

Aam Slamet Rusydiana, Abrista Devi

to change society mindset that Islamic takaful is totally different with conventional takaful. Society do really need more socialization rely on this matter.

Figure 3: The Results of the Synthesis of Main Problems to Develop Islamic Micro Takaful Product in Takmin Working Group

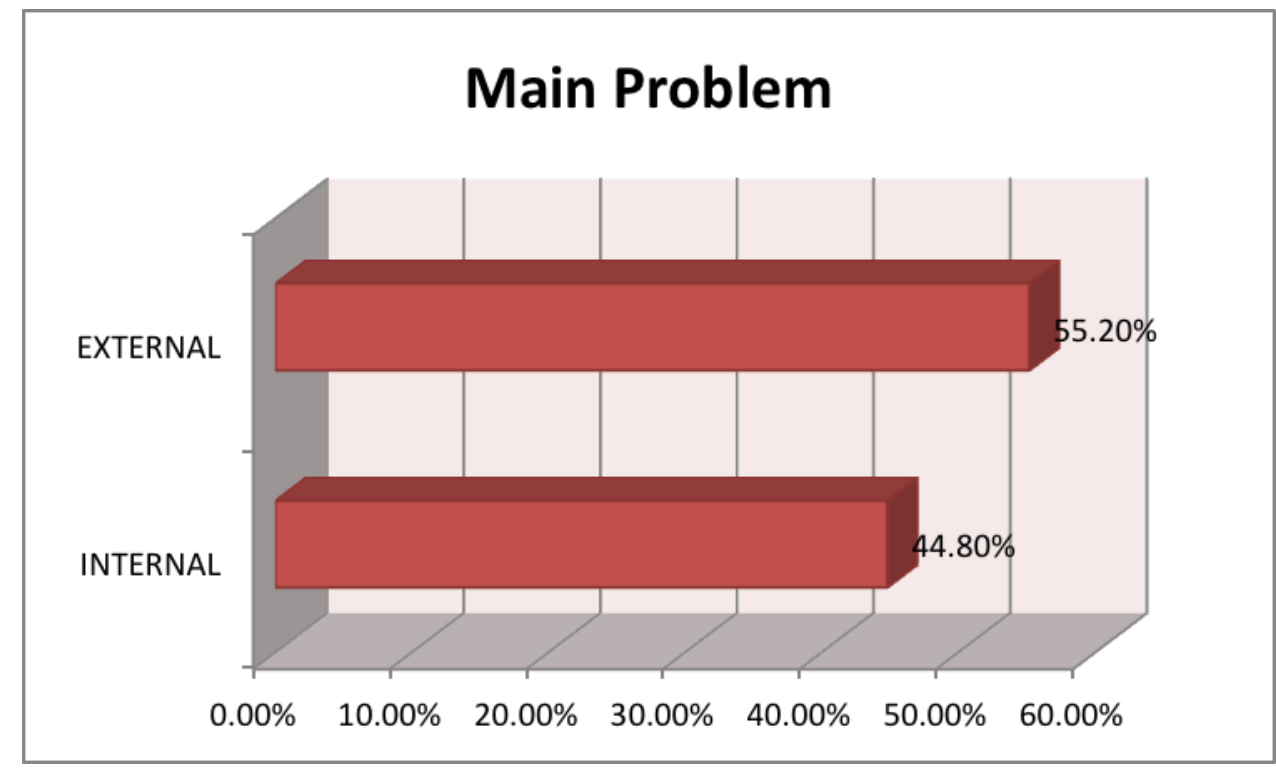

The highest priority problem concerned with sub criteria of internal institutions is Institution scale is relatively small with the ratio result is $53.9 \%$, and then followed by there are no agency sales $(23.8 \%)$, the lack of human resource capability $(13.9 \%)$, and the last priority is insufficient of promotion fund (8.4\%). Islamic micro takaful in Indonesia is relatively new compared to macro takaful and conventional takaful. The existence of micro takaful in Indonesia is considered of the significant development of Islamic micro finance institutions in Indonesia, such as Baitul mal wat Tamwil (BMT), Islamic cooperation, etc. The need of protection for micro business sector is also increasing at this time. So it is normal if the institution scale of Takmin Working Group is still small. The small institutions scale of TWG finally is affecting to their operational activities. Then TWG will grow slowly if they are not fully supported by other financial institutions such as Islamic bank, Islamic rural bank, and Islamic micro finance (See Figure 4).

The second priority is the lack of agency scale. Agency in Islamic Insurance has an important role in order to promote insurance product. Sumanto (2009) stated that insurance agency marketing has the function to keep the company image to the customer eyes. Insurance agency marketing has to avoid the mistake in promoting the insurance product, informing the product, and selling the product. Therefore, Islamic insurance agency marketing needs to work professionally, and has a good knowledge not only Islamic 
insurance knowledge but also economic knowledge. This knowledge is being the answer to the need of Islamic insurance market in Indonesia. (Firmansyah \& Devi, 2017) stated in their research that the fact, Islamic insurance agency marketing don't have the interest to promote and sell Islamic micro finance product. Islamic micro finance products are considered less profitable than conventional one. Islamic micro finance product will be profitable if only the agency can sell the product collectively not individually. So, the agency argues that it would be difficult to sell micro insurance product without having a strong relationship with some parties (such as company, community, etc).

Figure 4: The Results of the Synthesis of Internal Problems to Develop Islamic Micro Takaful Product in Takmin Working Group

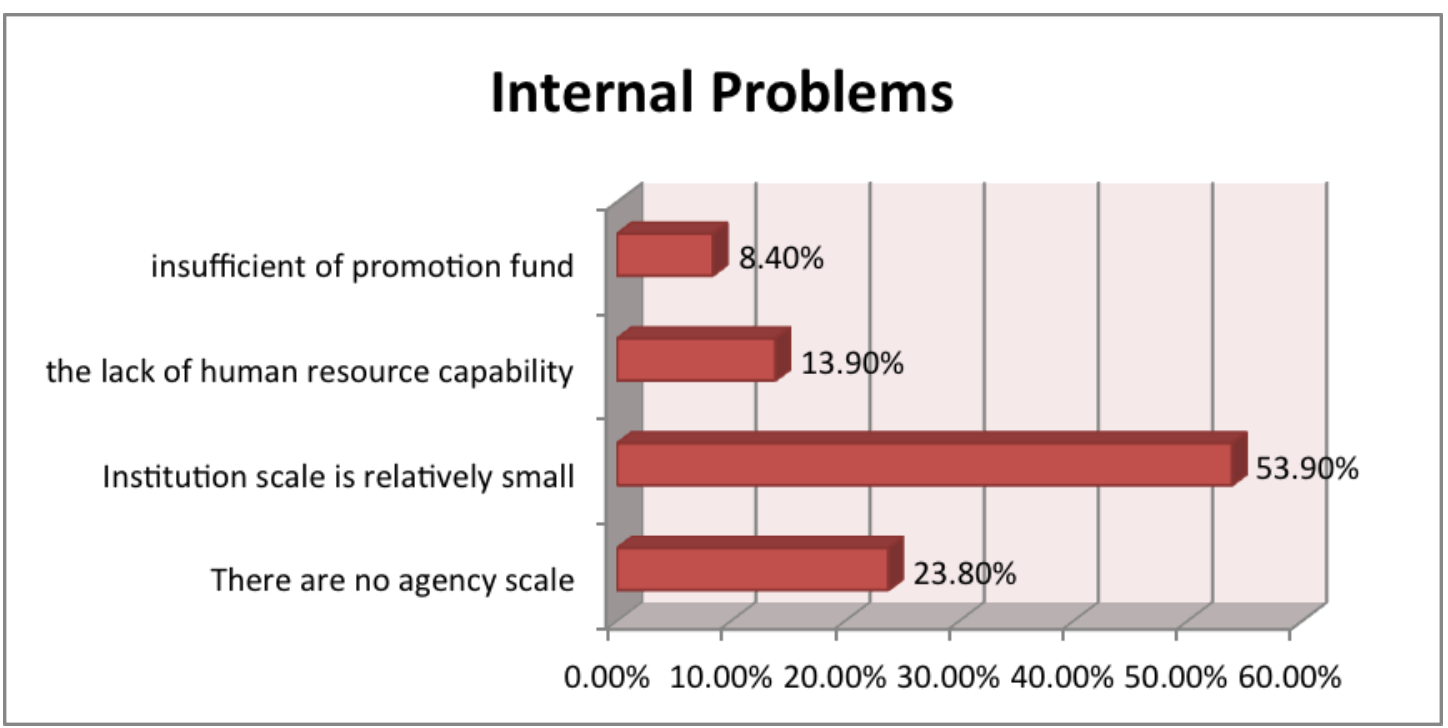

The last priority of internal problem is insufficient of promotion fund. It means that, fund is not the main constraint to develop micro takaful product. Integrated cooperation among financial institutions will directly help micro takaful to enhance their operational activities involve promoting their product to society. The highest priority problem concerned with sub criteria of external institutions is society paradigm about insurance with the ratio result is $39.9 \%$, and then followed by Islamic micro finance institutions routines activities (29.1\%), the saturated of market $(19.2 \%)$, and the last priority is market competition (11.7\%). Society paradigm about insurance is being the highest priority of external problems. According to our pre-research of this study using observation to some of respondents from the low income society, they argue if they do not know more details about what Islamic Micro insurance is, and what the benefits from Islamic Micro insurance are. In addition, they have less interest to have protection for their business. Based on this observation result, we can assume that the society have not 
Development Strategy of Micro-Takaful Institutions..........

Aam Slamet Rusydiana, Abrista Devi

awareness yet rely on the importance of Islamic Micro insurance especially to protect their business. So, it would be a great agenda, not only for Islamic micro finance institutions but also for regional government to socialize and educate people on how the importance of Islamic Micro insurance in order to protect their business. Malagardis, et al (2014) state on their study that the lack of information and understanding of takaful and micro takaful poses a challenge for both the regulator and the industry. This challenge must be overcome in contributing the growth of Islamic micro takaful industry especially in Indonesia. The details can be seen in Figure 5.

The second priority of external institutions problem is Islamic micro finance institutions routines activities. As commonly known, that the main function of Islamic micro finance institutions is giving the financing to the un-bank-able people, or low income society. It is normal if Islamic micro finance institutions will make financing program as their main program and make financing program more prioritize than others, but if Islamic micro finance institutions can build good cooperation with Takmin Working Group, hence it is expected to enlarge their scale of business for low income segment consumers.

Figure 5: The Results of the Synthesis of External Problems to Develop Islamic Micro Takaful Product in Takmin Working Group

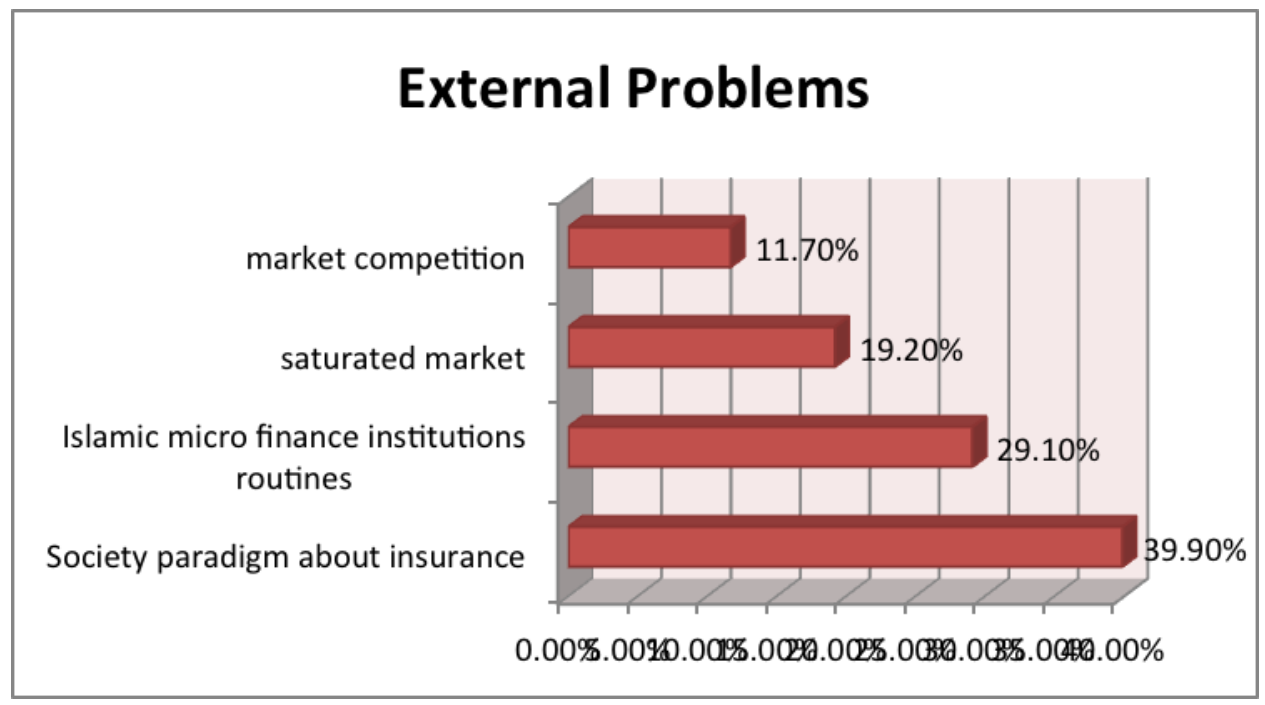

In compliance with problem cluster, the priority results showed that the most priority solution coming from information system development (32.8\%), and then followed by innovative product development $(30.2 \%)$, communication and visitation to Islamic micro finance institutions (25.8\%), and the last priority solution is doing the intensive socialization to society $(11.3 \%)$. The priority solutions clusters are shown on Figure 6. 
The main priority of solutions cluster in relevant to develop Islamic micro takaful product in Takmin Working Group is information system development. Takmin Working Group might have cooperation with information technology (IT) provider to develop the information system for supporting operational activities of Takmin Working Group. Information system technology is being the most considerable factors of business success today's era. All stakeholders expected are able to access all kind of information related to micro takaful operational activities. Unfortunately, micro institutions nowadays are lack supported of this system. The lack of information system support is not only being constraint for Islamic micro takaful institutions such as Takmin Working Group, but also being constraint for others Islamic micro finance institutions such as BMT (baitul mal wattamwi), Islamic cooperation, and others micro institutions. Takmin Working Group must cope with the importance of information system technology to enlarge the business capacity of TWG and also complement the need of consumers relies on Microinsurance product.

Figure 6: The Results of the Synthesis of Solutions to Develop Islamic Micro Takaful Product in Takmin Working Group

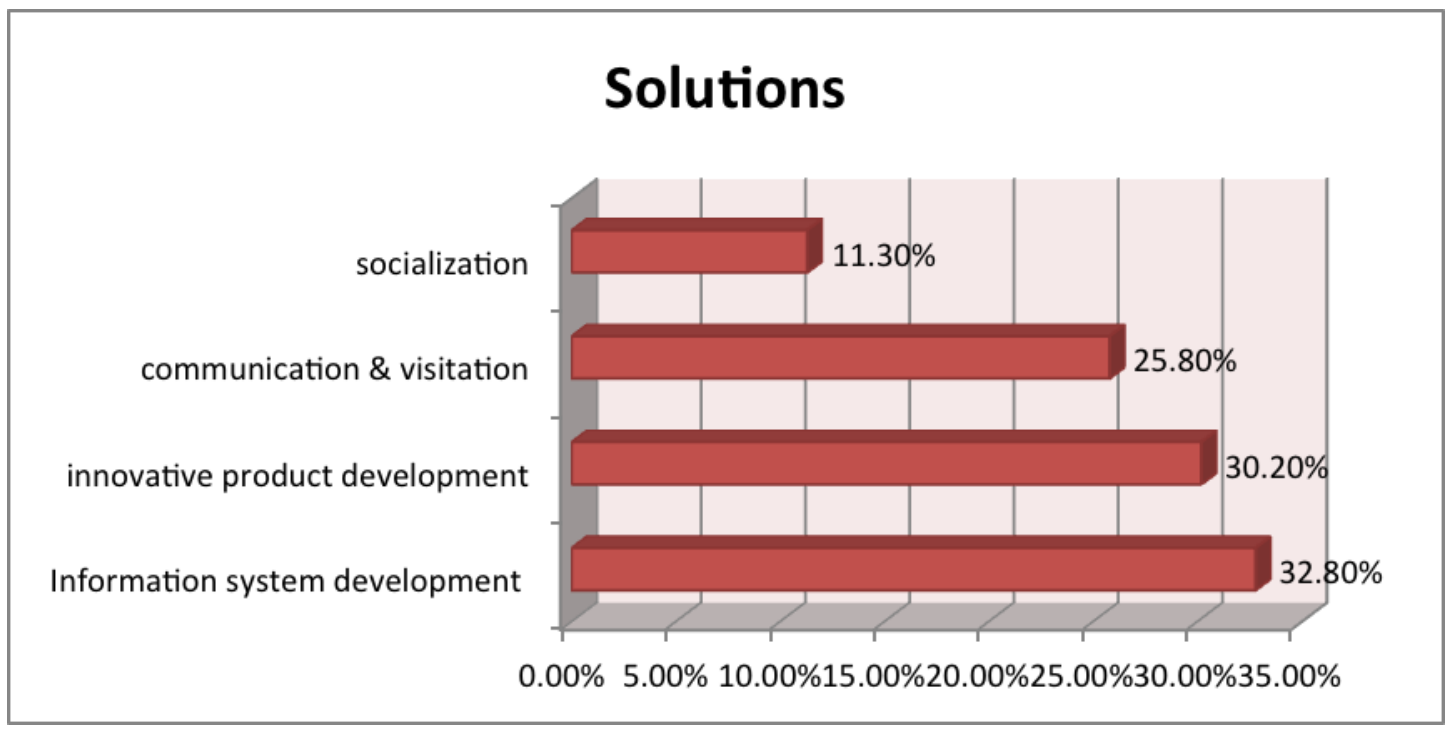

Yusuf (2012) also stated that the development of information system will affect to the effective and efficient of an Islamic micro insurance industry. The information system is being one of main factor to market the product in nowadays situations. Especially for the un-bankable prospective customer, rural customers officially need fast and accurate information regarding to the product, which their money invested inside them. Therefore, Islamic insurance especially in this case focuses on TWG has to increase their information system to achieve high market share of Islamic micro insurance product. Fadun (2013) 
Development Strategy of Micro-Takaful Institutions..........

Aam Slamet Rusydiana, Abrista Devi

stated that Insurance company need professionalism to reach good corporate governance through enhancing the information system technology. Because, this strategy would help insurance companies in promoting their product. It followed by risk management effectiveness.

The second priority to enhance the Islamic micro takaful product development is innovative product development. Takmin Working Group must develop innovative product in relevant to consumers need. In order to accommodate this program, TWG might be able to hire employee which has expertise in business development and also expertise in fiqh muamalah / muamalah transaction. TWG also can develop some products by combining Islamic contract transaction or commonly known as 'hybrid contract', without eliminating sharia compliance of the product, such as Ahmed, et al (2005) already tried to develop on health microfinance product.

Innovative development product not only can be carried out trough innovative product but also can be carried out by the price. The main segment of Islamic microtakaful is low-income people and the needy. Therefore, the prices (premiums) collections are suggested to comply with their income. Ahuja and Khasnobis (2015) suggested to insurance company in having the flexibility in premium collection of their product (microinsurance product). The flexibility in premium collection officially will affect to the intention of customer to join or not join the insurance. The low-income people commonly don't have particular timing to get cash of money (seasonal). Therefore, insurance company has to be able to understand this condition and gives some flexibility to collect the premium from this kind of people.

\section{CONCLUSION}

Based on the research and discussion above concerning the development of micro takaful institutions in Takmin Working Group, it can be concluded that there are twomain problems faced by Takmin Working Group in micro takaful institutions development, consisting of internal problem and external problem. The most priority problem is coming from external problem. The most priority of external problem is society paradigm about insurance, whether the most priority of internal problem is institution scale is relatively small. The research result also show that the most priority solutions that can be undertake by Takmin Working Group to solve these both internal and external problem is information system development, and then followed by innovative product development. 
Communication \& visitation to Islamic micro finance institutions and socialization about microtakaful product to society are being less priority on this matter.

Some recommendations could be addressed. There should be a mutual agreement among micro takaful stakeholders in supporting and promoting the socializations of micro takaful product to some consumer segments. Takmin Working Group should have a mutual agreement to some Islamic micro takaful institutions, regional government, community societies, and Islamic bank in order to reach this objective. Takmin Working Group should enlarge the segmentation of micro takaful costumer. TWG might not only focus to micro business but also can reach another segment market. The future consumers also must be informed intensively by Takmin Working Gorup about its eligibility, distinction of features (if it is compared to conventional insurance) and also they must be informed about the price and payment style.

\section{REFERENCES}

Ahmed, M., Islam, S., Quashem, M \&Ahmed,N. (2005). Health Microinsurance; A Comparative Study of Three Examples in Bangladesh. Bangladesh: CGAP

Ahuja, R., \& Khasnobis, B.G. (2005). Micro-Insurance in India: Trends and Strategies for Further Extension. Working Paper No. 162. Indian Council for Research on International Economic Relations.

Fadun, O.S. (2013). Corporate Governance and Insurance Company Growth: Challenges and Opportunities. International Journal of Academic Research in Economics and Management Sciences. 2 (1): 286-305.

Firmansyah, I \& Devi, A. (2017). Optimalisasi Good Corporate Governance untuk Pengembangan Asuransi Mikro Syariah sebagai Bentuk Penguatan Peran IKNB dalam Meminimalisir Risiko UMKM (Optimalization of Good Corporate Governance to the Development of Micro-takaful in Strengthen the Role of NonBanks Institution in Minimizing the Risk of SMEs). Proceeding at Call For Papers Non-Bank Financial Industry 2017, held by Otoritas Jasa Keuangan (OJK).

Hariyadi, E \& Triyanto, A. (2017). Peran Agen Asuransi Syariah dalam Meningkatkan Pemahaman Masyarakat tentang Asuransi Syariah (The Role of Islamic Insurance Agent to Improve the People Awareness in Islamic Insurance). Jurnal Ekonomi dan Perbankan Syariah, 5 (1): 19-37. 
Development Strategy of Micro-Takaful Institutions

Aam Slamet Rusydiana, Abrista Devi

Hasim, Hasilifah Mohammad. (2014). Developing a Conceptual Framework of Microtakaful as a Strategy towards Poverty Alleviation. Journal of Economics and Sustainable Development. 5 (28): 1-9.

Malagardis, A., Muchlasin, M., \& Utami, S. (2014). Market Assessment on Microtakaful in Indonesia. This research was carried out by GIZ RFPI Asia and supported by OJK and AASI. This paper also already presented at Microtakaful conference Indonesia, Jakarta, 24 April 2014.

Obaidullah, M., \& Tariqullah. (2008). Islamic Microfinance Development: Challenges and Initiatives. Working Paper No. 2. Islamic Research and Training Institute Policy Dialogue.

Rusydiana, A.S. \& Devi, A. (2013). Challenges in Developing Baitul Maal wat Tamwil in Indonesia using Analytic Network Process. Business Management Quarterly Review. 4(2): 51-62.

Sumanto \& Agus, E.P. (2009). Solusi Berasuransi: Lebih Indah dengan Syariah (Insurance Solution: More Beautiful with Sharia). Bandung: PT Salamdani Pustaka Semesta.

Yusuf, T.O. (2012). The Role of Islamic Micro Insurance in Economic Growth and Development: The Nigerian Experience: A Case Study of Al-Barakah Microfinance Bank, Lagos. International Journal of Business and Commerce. 1 (10): 106-122. 